\title{
ONTOGENETIC ASPECTS OF MELATONIN RECEPTORS 1 A DENSITY IN THE LATERAL PREOPTIC NUCLEUS OF THE HYPOTHALAMUS UNDER VARIOUS LIGHT CONDITIONS
}

DOI: 10.36740/WLek202109131

\author{
Roman Ye. Bulyk, Vladyslav R. Yosypenko, Kateryna V. Vlasova \\ BUKOVINIAN STATE MEDICAL UNIVERSITY, CHERNIVTSI, UKRAINE
}

\begin{abstract}
The aim: To find out density of melatonin receptors $1 \mathrm{~A}$ in the neurons of the lateral preoptic nucleus of the hypothalamus in mature and old rats under various light conditions. Materials and methods: The study was carried out on 72 albino mature and old rats with light conditions appropriate for the experiment. To find out circadian differences of melatonin receptors $1 A$ the material for the study was taken at 2 p.m. and 2 a.m. Visualization of primary antibodies against melatonin receptors $1 A$ (Abcam) was conducted by means of the polymeric system Dako and diaminobenzidine staining under the microscope Delta 0ptical Evolution 100. The intensity of staining was assessed on the digital copies of images according to computer microdensitometry method.

Results: Immunohistochemical examinations conducted enable to suggest that melatonin receptors $1 \mathrm{~A}$ in the neurons of the lateral preoptic nucleus of the hypothalamus respond to different light conditions. In particular, intensity of immunohistochemical staining to melatonin receptors $1 \mathrm{~A}$ under conditions of light deprivation increases both in mature and old rats, but it decreases under conditions of light stimulation. The parameter is higher at 2 a.m. as compared with 2 p.m. Intensity of immunohistochemical staining to melatonin receptors $1 A$ in the neurons of the lateral preoptic nucleus of the hypothalamus is always lower in old rats than in mature ones.

Conclusions: Density of melatonin receptors $1 \mathrm{~A}$ in the neurons of the lateral preoptic nucleus of the hypothalamus is subordinated to the circadian rhythm: it increases at night and decreases in the daytime. At the same time, light stimulation results in disorders of the rhythm and development of desynchronization.
\end{abstract}

KEY WORDS: sleep-wake cycle, lateral preoptic nucleus of the hypothalamus, chronological rhythms, lighting, melatonin

Wiad Lek. 2021;74(9 p.l):2202-2206

\section{INTRODUCTION}

Physiological processes in living systems are subordinated to regular cyclic fluctuations - biological rhythms [1]. Cyclic character of biological functions at all the levels of life organization is one of the major properties of biological systems [2]. Circadian rhythms appeared to be the most valuable among all biological rhythms [3], belonging to freely progressing endogenous rhythms [4] which last approximately for 24 hours [3]. They are associated with cyclic changes of day and night, that is, revolving of the Earth about its axis [5]. Nowadays circadian rhythms of motor activity, temperature of the body and skin, pulse and respiration rates, blood pressure, diuresis and others are available [4].

24-hour circadian sleep-wake cycle is peculiar for people [6], though sleep is something more than simply a part of the circadian system [7]. Sleep constitutes approximately a third of the human life, and its quality determines general level of health [8]. Sleep is a complicated physiological process requiring interaction of various areas of the brain [9]. Sleep consists of two phases: slow-wave sleep and rapid eye movement sleep [8]. Night sleep consists of 4-5 such cycles lasting about 90-100 minutes [4].

An important component in regulation of the sleep-wake cycle is structures located in the anterior hypothalamus, and the lateral preoptic nucleus in particular [4]. The neurons of the nucleus contain neurotransmitters galanin and gamma-aminobutyric acid which provide inhibiting innervation of the major monoamine systems of the brain that determine the period of wake [10].

The pineal gland is evidenced to participate in the regulation of the sleep-wake cycle by means of synthesis of neurohormone melatonin [3]. Melatonin secretion is of circadian character: in a dark period melatonin concentration in the blood is 5-10 times as much than in the daytime. The level begins to increase in the evening reaching the maximum from 60 to $100 \mathrm{mg} / \mathrm{ml}$ at 2 a.m. -4 a.m., then it decreases gradually from 7 a.m. to 8 p.m. and remain low - lower than $20 \mathrm{mg} / \mathrm{ml}$ [11]. Available circadian rhythm of melatonin production is a marker of normal work of the circadian system of endogenous biological rhythms and their synchronization with changes of day and night [12] and regulation of the sleep-wake cycle [8]. Melatonin secretion decreases with age [13]. Its average daily concentration in elderly people is $50 \%$ lower than that of the young [14]. Sleep regimen changes with age as well. It is manifested by shorter general time of sleep [15] and changes of periods of sleep phases [16].

Disorders of the sleep-wake cycle result in psychiatric and neurodegenerative diseases [17], an in- 
creased risk of development of oncological, metabolic, cardiovascular diseases [5] and untimely death [18]. Recent investigations demonstrate that short sleep (less than 5 hours) among individuals under 65 years of age during weekends is associated with a higher level of mortality rate up to $52 \%$ [19]. Insufficient sleep causes development of metabolic syndrome and obesity. Sleep 1 hour shorter a day is associated with an increasing body mass index up to $0,35 \mathrm{~kg} / \mathrm{m}^{2}$ [14]. Light conditions are of great importance as well. Lower light intensity in the morning and brighter light in the evening can also provoke sleep disorders [6].

Therefore, investigation of the fundamental mechanisms in the regulation of the sleep-wake cycle is an essential term to solve these issues. Melatonin produces certain effect on the target organs binding with specific receptors in the plasmatic membrane and nucleus [16]. Availability of melatonin receptors in the lateral preoptic nucleus of the hypothalamus is a convincing criterion of the nucleus participation in time organization.

\section{THE AIM}

The aim was to find out density of melatonin receptors $1 \mathrm{~A}$ in the neurons of the lateral preoptic nucleus of the hypothalamus in mature and old rats under various light conditions.

\section{MATERIALS AND METHODS}

The experiments were carried out on albino non-linear mature and old male rats. The experimental animals were distributed into six groups. In their turn, they contained two subgroups six animals each. Group №1 contained mature rats kept for seven days under standard light conditions (light by means of fluorescent lamps from 8 a.m. to 8 p.m., illumination level - $500 \mathrm{~lx}$ ). Group №2 contained mature rats kept under conditions of complete darkness during 24 hours (light deprivation) during the similar period of time. Group №3 contained mature rats kept for seven days under conditions of twenty-four-hour light (light stimulation). Group №4 contained old rats kept during seven days under standard light conditions (level and time of illumination similar to that of mature rats). Group №5 contained old rats kept during seven days under complete darkness conditions. Group №6 contained old rats kept under conditions of twenty-four-hour light during the whole similar period.

The following day on completion of the experiment single-stage decapitation of rats was performed under ethaminal narcosis $(40,0 \mathrm{mg} / \mathrm{kg}$, injected into the peritoneum) at 2 p.m. and 2 a.m. with the purpose to find circadian differences in the density of melatonin receptors 1A. All the stages of the experiment were conducted after obtaining approval from the biomedical ethics committee of Bukovinian State Medical University and keeping to the orders of the Ministry of Health of Ukraine № 690 dated 23.09.2009, № 944 dated 14.12.2009, № 616 dated 03.08.2012 and the Laws of Ukraine, Council Directive
86/609/EEC of 24 November 1986 on the approximation of laws, regulations and administrative provisions of the Member States regarding the protection of animals used for experimental and other scientific purposes, European Convention on protection of vertebrate animals used for experimental and other scientific purposes (18.03.1986) and the main principles of the First National Congress Resolution on bioethics «General Ethic Principles of Experiments on Animals» (2001).

After decapitation removed brain was kept for 22-24 hours in neutral extra-buffer $10 \%$ formalin solution. Small incisions were made in the soft brain matter for better formalin penetration into the brain tissues. The laminae about one millimeter thick were cut from the preserved tissue. The first cut passed through the anterior part of the optic chiasm, and the second cut - through the posterior part of the optic chiasm. Then the cut out laminae of the brain were dehydrated in a ascending battery of alcohols, paraffin was poured at $58^{\circ} \mathrm{C}$, and series of histological sections were made $5 \mathrm{mcm}$ thick on the sliding microtome. Immunohistochemical methods were applied on the sections according to the protocols supplied by the producer. Thus, primary antibodies against melatonin receptors $1 \mathrm{~A}$ were used (Abcam). Primary antibodies were visualized by means of the microscope Delta Optical Evolution 100 and digital camera Olympus SP550UZ according to the polymeric system Dako and diaminobenzidine staining, which gives a brown color of the spots where examined antigens are located.

The intensity of staining was assessed on the digital copies of images according to computer microdensitometry method by means of the licensed copy of the computer program ImageJ v1.48. At the beginning computer value of staining brightness was determined by means of microprobe method in the 8-bit system of analysis. After that these values were transformed into the value of relative optic density (in the units of optic density) by means of logarithmic transformation in the range from 0 (absolute transparence) to 1 (absolute opacity).

The results obtained were statistically processed by means of the licensed copy of the computer program PAST. Shapiro-Wilkie criterion was used to check a normal distribution. According to this criterion hypothesis about normal distribution did not deviate, therefore parametric methods of statistical analysis were applied: calculation of the arithmetic mean and its error $(\mathrm{M} \pm \mathrm{m})$, odd bilateral Student criterion. At the same time, in order to ensure reliability of the results to check differences between groups of the study in average tendencies considering comparatively small amount in statistical samples, Mann-Whitney criterion was additionally used.

\section{RESULTS}

A specific feature of melatonin receptors $1 \mathrm{~A}$ in the neurons of the lateral preoptic nucleus of the hypothalamus was that specific immunohistochemical staining could be observed irrespective of their localization by the nucleus. 
Table I. Optic density of specific staining to melatonin receptors $1 A$ in the neurons of the lateral preoptic nucleus of the hypothalamus of rats ( $\mathrm{M} \pm \mathrm{m}$ )

\begin{tabular}{|c|c|c|}
\hline \multirow{2}{*}{ Hours of the day } & \multicolumn{2}{|c|}{$\begin{array}{l}\text { Optic density of immunohistochemical staining to melatonin receptors } 1 \mathrm{~A} \\
\text { (in the units of optic density) }\end{array}$} \\
\hline & Mature rats & Old rats \\
\hline 2 p.m. & $0,248 \pm 0,0018$ & $\begin{array}{l}0,211 \pm 0,0014 \\
\left(p_{2}<0,001\right)\end{array}$ \\
\hline 2 a.m. & $\begin{array}{l}0,264 \pm 0,0016 \\
\left(p_{1}<0,001\right)\end{array}$ & $\begin{array}{c}0,216 \pm 0,0013 \\
\left(p_{1}<0,05\right) \\
\left(p_{2}<0,001\right)\end{array}$ \\
\hline
\end{tabular}

Note: $p_{1}$ - probability of difference as compared with the previous time interval; $\mathrm{p}_{2}$ - probability of difference as compared with another group of the study.

Table II. Specific staining optic density to melatonin receptors $1 A$ in the neurons of the lateral preoptic nucleus of the hypothalamus of rats under conditions of light deprivation $(\mathrm{M} \pm \mathrm{m})$

\begin{tabular}{|c|c|c|}
\hline \multirow[t]{2}{*}{ Hours of the day } & \multicolumn{2}{|c|}{$\begin{array}{l}\text { Optic density of immunohistochemical staining to melatonin receptors } 1 \mathrm{~A} \\
\text { (in the units of optic density) }\end{array}$} \\
\hline & Mature rats & Old rats \\
\hline 2 p.m. & $0,280 \pm 0,0019$ & $\begin{array}{l}0,234 \pm 0,0010 \\
\left(p_{2}<0,001\right)\end{array}$ \\
\hline 2 a.m. & $\begin{array}{l}0,298 \pm 0,0017 \\
\left(p_{1}<0,001\right)\end{array}$ & $\begin{array}{c}0,267 \pm 0,0016 \\
\left(p_{1}<0,001\right) \\
\left(p_{2}<0,001\right)\end{array}$ \\
\hline
\end{tabular}

Note: $p_{1}$ - probability of difference as compared with the previous time interval; $\mathrm{p}_{2}$ - probability of difference as compared with another group of the study.

Table III. Specific staining optic density to melatonin receptors 1A in the neurons of the lateral preoptic nucleus of the hypothalamus of rats under conditions of light stimulation $(\mathrm{M} \pm \mathrm{m})$

\begin{tabular}{|c|c|c|}
\hline \multirow[t]{2}{*}{ Hours of the day } & \multicolumn{2}{|c|}{$\begin{array}{l}\text { Optic density of immunohistochemical staining to melatonin receptors } 1 \mathrm{~A} \\
\text { (in the units of optic density) }\end{array}$} \\
\hline & Mature rats & Old rats \\
\hline 14.00 & $0,180 \pm 0,0018$ & $\begin{array}{l}0,148 \pm 0,0013 \\
\left(p_{2}<0,001\right)\end{array}$ \\
\hline 02.00 & $\begin{array}{l}0,182 \pm 0,0017 \\
\quad\left(p_{1}>0,05\right)\end{array}$ & $\begin{array}{c}0,132 \pm 0,0012 \\
\left(p_{1}<0,001\right) \\
\left(p_{2}<0,001\right)\end{array}$ \\
\hline
\end{tabular}

Note: $p_{1}$ - probability of difference as compared with the previous time interval;

$\mathrm{p}_{2}$ - probability of difference as compared with another group of the study.

Staining involved both membrane of the neurons and their cytoplasm and was mainly of fine-granular or practically diffuse character. Examining staining intensity from one neuron to another we can suggest that it was of different effect concerning both the membrane and cytoplasm. Thus, there were neurons with intense, moderate, and even mild staining, therefore optic density of specific staining to melatonin receptors $1 \mathrm{~A}$ in the neurons of the lateral preoptic nucleus of the hypothalamus was measured on the cellular cytoplasm where staining was of a stable character. Average values of the optic density of staining to melatonin receptors $1 \mathrm{~A}$ in the neurons of the lateral preoptic nucleus of the hypothalamus of rats kept under standard light conditions at 2 p.m. and 2 a.m. are presented in Table I.

Under conditions of light deprivation we have found the highest average values of the specific staining optic density to melatonin receptors $1 \mathrm{~A}$ in the neurons of the lateral preoptic nucleus of the hypothalamus, which was especially seen in mature rats (Table II).

Under conditions of twenty-four-hour illumination the intensity of optic density of specific staining to melatonin receptors $1 \mathrm{~A}$ in the neurons of the lateral preoptic nucleus of the hypothalamus decreased sharply, which was seen on the optic density of staining (Table III).

\section{DISCUSSION}

Lighting conditions are very important for normal sleep. Decrease in light intensity in the morning or increase in the evening [6] and human activity at night - the most common causes of sleep-wake rhythm disorders [18] which are accompanied by inhibition of melatonin synthesis and secretion and lead to the development of desynchrony [11]. 
Our research illustrates that the optic density of staining to melatonin receptors $1 \mathrm{~A}$ in the neurons of the lateral preoptic nucleus of the hypothalamus in mature rats is always higher than that in the old ones. Moreover, in mature rats, the optic density of staining to melatonin receptors $1 \mathrm{~A}$ in the neurons of the lateral preoptic nucleus of the hypothalamus at $2 \mathrm{a} . \mathrm{m}$. is on an average higher than that at 2 p.m., such a tendency is not found among old rats. At the same time, in old rats irrespective of lower average values of the specific staining optic density to melatonin receptors $1 \mathrm{~A}$ in the neurons of the lateral preoptic nucleus of the hypothalamus, rather intensive staining could be observed in certain neurons.

Under conditions of light deprivation maximal amounts of the optic density of staining were found at 2 a.m. of the experiment. At the same time, certain neurons occurred with especially intensive staining, but it was not even in those cases but was of specific asymmetric character the highest intensity of staining was found in one of the cellular poles.

In old rats under conditions of twenty-four-hour darkness intensity of optic density of specific staining to melatonin receptors $1 \mathrm{~A}$ in the neurons of the lateral preoptic nucleus of the hypothalamus increased as compared with rats kept under usual light conditions. At the same time, optic density of specific staining to melatonin receptors $1 \mathrm{~A}$ was higher at $2 \mathrm{a} . \mathrm{m}$. as compared with 2 p.m. it should be noted that at 2 a.m. in old rats optic density of specific staining to melatonin receptors $1 \mathrm{~A}$ reached average amounts, which were peculiar for mature rats at 2 a.m. kept under usual light conditions (Table I). In old rats at 2 a.m. in certain neurons of the lateral preoptic nucleus of the hypothalamus the intensity of specific staining was especially marked, though certain neurons were found to be weak stained.

Decreasing the intensity of optic density of specific staining to melatonin receptors $1 \mathrm{~A}$ in the neurons of the lateral preoptic nucleus of the hypothalamus was seen in both mature and old rats, and this decrease was especially significant in the latter ones. At the same time, there were no differences registered in the average tendencies between specific staining optic density in the neurons of the lateral preoptic nucleus of the hypothalamus at 2 a.m. and 2 p.m. in mature rats. Though, in old rats intensity is paradoxically lower at 2 a.m. than at 2 p.m.

\section{CONCLUSIONS}

1. Density of melatonin receptors $1 \mathrm{~A}$ in the neurons of the lateral preoptic nucleus of the hypothalamus in old rats is lower than that of the mature animals.

2. Under standard light conditions the density of melatonin receptors $1 \mathrm{~A}$ in the neurons of the lateral preoptic nucleus of the hypothalamus is subordinated to regular circadian fluctuations: the highest values are found at 2 a.m., while at 2 p.m. they decrease.

3. Under conditions of light deprivation the density of melatonin receptors $1 \mathrm{~A}$ in the neurons of the lateral preoptic nucleus of the hypothalamus increases both in mature and old rats with its maximal value at 2 a.m. And intensity of staining is of asymmetrical character.

4. Under conditions of light stimulation circadian rhythm disorders are found and the density of melatonin receptors $1 \mathrm{~A}$ in the neurons of the lateral preoptic nucleus of the hypothalamus in mature and old rats decreases. At the same time, intensity of melatonin receptors $1 \mathrm{~A}$ density in old rats at 2 a.m. is paradoxically lower than that at 2 p.m.

\section{REFERENCES}

1. Vlasenko N.Yu., Vlasenko M.A. Osobennosti tsirkadiannogo ritma kortizola cheloveka pri vynuzhdennoy deprivatsii sna. Izvestiya Irkutskogo gosudarstvennogo universiteta Seriya «Biologiya.Ekologiya». 2019; 30 : 105-115. (in Russian).

2. RapoportS.I. Khronomeditsina, tsirkadiannye ritmy. Komu eto nuzhno? Klinicheskaya meditsina. 2012; 8:73 - 75. (in Russian).

3. Kel'manson I.A. Khronopatologicheskie aspekty rasstroystv sna i kognitivnykh funktsiy u detey s narusheniyami zreniya. Rossiyskiy vestnik perinatologii i pediatrii. 2015;5: 42 - 50. (in Russian).

4. Zakharchuk 0.I.Vzaiemozviazok rozladiv khronostruktury tsyrkadiannykh rytmiv ta porushen tsyklu «son-nespannia». Molodyi vchenyi. 2014; 10 (5): 94 - 97. (in Ukrainian).

5. Chaulin A.M., Duplyakova P.D., Duplyakov D.V. Tsyrkadnye ritmy serdechnykh tropinov: mekhanizmy i klinicheskoe znachenie. Rossiyskiy kardiologicheskiy zhurnal. 2020; 25 (3): 62 - 69. (in Russian).

6. Akarachkova E.S., Tsareva E.V. Rasstroystva sna, svyazannye s tsirkadiannym ritmom. Stress pod kontrolem. 2019;1:9-19.

7. Baron K.G., Reid K.J.Circadian misalignment and health. Review Int Rev Psychiatry. 2014; 26(2): 139-54.

8. Berdina 0.N., Madaeva I.M., Rychkova L.V. Ozhirenie i narusheniya tsirkadnykh ritmov sna i bodrstvovaniya: tochki soprikosnoveniya i perspektivy terapii. Acta biomedica scientifica. 2020; 5 (1): 21-30. (in Russian).

9. Flomin Yu.V. Rasstroystva sna u patsientov s insul'tom: vyyavlenie, klinicheskoe znachenie i sovremennye podkhody k lecheniyu. Mezhdunarodnyy nevrologicheskiy zhurnal. 2014; 1 (63): 89 - 100. (in Russian).

10. Kroeger D., Absi G., Gagliardi C. et al. Galanin neurons in the ventrolateral preoptic area promote sleep and heat loss in mice. Nature Communications. 2018; 9: 1-14.

11. Pishak V.P., Bulyk R.le., Kryvchanska M.I. et al. Osnovni fiziolohichni vlastyvosti melatoninu. Intehratyvna antropolohiia. 2015; 1 (25):32-38. (in Ukrainian).

12. Aylamazyan E.K., Evsyukova I.I., Yarmolinskaya M.I. Rol' melatonina v razvitii gestatsionnogo sakharnogo diabeta. Akusherstvo i zhenskikh bolezney. 2018; 67(1) : 85 - 91. (in Russian).

13. ZakharchukA.Y., Kadelnyk L.A. Melatonyn y herontolohycheskye aspektb sezonnoi strukturb tsyrkadyannыkh rytmov nespetsyfycheskoho ymmunyteta. Health \& education millennium. 2013;15(1):259-262. (in Ukrainian).

14. Strueva N.V., Poluektov M.G., Saval'eva L.V. et al. Ozhirenie i son. Ozhirenie i metabolizm. 2013;3:11-18. (in Russian).Soltani S, Chauvette $\mathrm{S}$, Bukhtiyarova 0, et al. Sleep-wake cycle in young and older mice. Front Syst Neurosci. 2019; 13: 51.

15. Kuznetsov V.V., Shevchenko L.A. Osobennosti sna i tsirkadnykh ritmov pri starenii. Zhurnal nevrologiï im. B.M. Man'kovs'kogo'. 2019; 7 (3): 47-56. (in Russian). 
16. Wahl S., Engelhardt M., Schaupp P. et al. The inner clock - blue light sets the human rhythm. Journal of Biophotonics. 2019; 12 (3): 1 - 14.

17. Koval'zon V.M., Dorokhov V.B. Tsikl bodrstvovanie-son i bioritmy cheloveka pri razlichnykh rezhimakh cheredovaniya svetlogo i temnogo perioda sutok. Health \& education millennium. 2013; 15 (1): 151 - 162. (in Russian).

18. Akerstedt T., Ghilotti F., Grotta A. et. al. Sleep duration and mortality Does weekend sleep matter? J Sleep Res. 2019; 28(1): e12712.

The study is a fragment of the scientific-research work of the Department of Medical Biology and Genetics "Morphofunctional and Biochemical Substantiation of Dysfunctions of the Neurosecretory Structures of the Brain and Endocrine Glands and Hepatorenal System of Rats with Experimental Pathology in the Age Aspect and the Ways of its Correction" (code of the theme: 0119 U101346 - fundamental).

\section{ORCID and contributionship:}

Roman Ye. Bulyk: 0000-0003-0651-534X E-F

Vladyslav R. Yosypenko: 0000-0002-8018-1627 B-D

Kateryna V. Vlasova: 0000-0001-7273-9021 ${ }^{\mathrm{A}}$

\section{Conflict of interest:}

The Authors declare no conflict of interest.

\section{CORRESPONDING AUTHOR}

\section{Vladyslav R. Yosypenko}

Bukovinian State Medical University

2 Teatralna Sq., 58001 Chernivtsi, Ukraine

tel: +380951275650

e-mail: v.yosypenko@bsmu.edu.ua

Received: 08.10 .2020

Accepted: 02.08.2021

A - Work concept and design, B - Data collection and analysis, C - Responsibility for statistical analysis,

D-Writing the article, $\mathbf{E}$-Critical review, $\mathbf{F}$ - Final approval of the article 